\title{
METODE IJTIHAD LEMBAGA MAJLIS AGAMA ISLAM PROVINSI PATTANI THAILAND SELATAN
}

\author{
Muhammadrodee Ka-nga \\ Hamzah \\ Alumni Pascasarjana UIN Alauddin Makassar \\ Dosen Fakultas Syariah dan Hukum Islam UIN Alauddin Makassar \\ deekanga.7841@gmail.com \\ hamzahhasan463@yahoo.com
}

\begin{abstract}
Abstrak: Tulisan ini akan mengurai tentang bagaimana metode ijtihad Majlis Agama Islam Provinsi Pattani Thailand Selatan dalam menetapkan hukum distribusi daging qurban kepada non-Muslim. Jenis penelitian ini adalah penelitian kualitatif yang mengambil lokasi di Majlis Agama Islam Provinsi Pattani Thailand Selatan. Pendekatan yang digunakan adalah pendekatan teologis normatif dan sosiologis. Sumber data primer diperoleh dari lembaga Majlis Agama Islam Provinsi Pattani Thailand Selatan, melalui wawancara dan catatannya dalam berijtihad tentang hukum distribusi daging qurban kepada non-muslim. Data dikumpulkan dengan metode wawancara, observasi, dan dokumentasi dengan instrumen penelitian adalah pedoman wawancara dan pedoman observasi. Teknik pengolahan dan analisis terhadap data dilakukan dengan reduksi data, display data dan verifikasi data. Pengujian keabsahan data, peneliti menekankan pada uji kredibilitas data atau kepercayaan terhadap hasil penelitian melalui beberapa tahap antara lain; memperpanjang pengamatan, meningkatkan ketekunan dalam penelitian, melaksanakan triangulasi sumber data maupun teknik pengumpulan data, melakukan diskusi dengan sejawat/orang yang berkompeten menyangkut persoalan yang sedang diteliti, serta mengadakan member chek untuk memastikan kesesuaian data yang telah diberikan oleh pengurus. Hasil penelitian menunjukkan bahwa metode ijtihad Majlis Agama Islam Provinsi Pattani Thailand Selatan dalam menetapkan hukum distribusian daging qurban kepada non-Muslim. Menggunakan metode ijtihad bayāni dan metode ijtihad istișlāhi. Metode ijtihad bayāni yang berdasarkan kepada zahir nash al-Qur'an dan hadis Nabi saw. Adapun ijtihad istislăhi, melihat secara kemaslahatan dan keagamaan yaitu tujuan ibadah qurban dalam bentuk sikap kasih sayang terhadap umat sesama muslim dengan cara memberikan makanan atau sedekah kepadanya. Dan qurban merupakan suatu ibadah, untuk hamba taat dan mendekatkan diri kepada Allah swt. maka yang boleh hanya ahli ibadah. Sementara nonMuslim di Pattani adalah kafir musyrik beragama budha yakni bukan ahli ibadah.
\end{abstract}

Keywords: Metode Ijtihad; Majlis Agama Islam; Ijtihad Bayani; Ijtihad Istislahi 


\section{PENDAHULUAN}

Hukum Islam itu berdasarkan dari al-Qur'an dan Hadis Nabi saw. tetapi sekarang banyak masalah-masalah, apalagi yang berkaitan dengan masalah furūi $\bar{i} \bar{a} h$ harus ditetapkan atau diputuskan hukumnya, yang tidak terdapat nashnya dalam al-Qur'an dan Hadis, kecuali harus menggunakan hasil ijtihad para Ulama mujtahid atau Ulama ahli mazhab.

Umat Islam di Thailand mempunyai sejarah yang cukup panjang dalam kerajaan thailand. Thailand adalah salah satu dari negara Asia Tenggara yang apabia ditinjau dari sudut agama yang dianut oleh penduduknya, mayoritas beragama Budha. Umat Islam adalah penduduk minoritas dari jumlah totalias penduduk Thailand, Mayoritas umat Islam di Thailand tinggal di wilayah selatan Thailand, yaitu daerah yang disebut dengan Pattani, daerah ini meliputi provinsi Pattani, Yala, Narathiwat, Setul dan sebagian Senggora, dihuni oleh sekitar 5 juta lebih jiwa yakni $8 \%$ dari jumlah seluruh penduduk Thailand yang berjumlah 69 juta lebih jiwa. Di wilayah ini dihuni oleh sekitar $85 \%$ masyarikat muslim. ${ }^{1}$

Masuknya Islam ke Pattani tidak bisa dilepaskan dengan masuknya Islam ke Asia Tenggara. Rentetan penyiaran Islam di Nusantara ini merupakan satu kesatuan dari mata rantai proses Islammisasi di Nusantara. Hal ini tentu terkait dengan seputar pendapat yang menjelaskan tentang masuknya Islam ke Nusantara yang secara garis besar dibagi pada dua pendapat, yakni pendapat yang mengatakan Islam mesuk ke wilayah ini pada abad ke tujuh Masehi dan langsung dari Arab dan pendapat yang mengatakan Islam masuk ke Nusantara pada abad ketiga belas Masehi berasal dari India.

Sejarah awal Pattani diperkirakan muncul pada tahun 1390. Raja Islam pertama Kerajaan Pattani adalah Sultan Isma'il Syah (1500-1539). Beliaulah peletak dasar Kerajaan Melayu Islam Pattani. Sejak kemunculan kerajaan Islam Pattani ini selalu saja terjadi perjuangan untuk melepaskan diri dari pengaruh Saim. Sultan Midzaffar Syah (1530-1564) pernah berupaya dua kali untuk menyerang dan menundukkan kota Ayuthia ibu kota Kerajaan Siam tetapi gagal.

Islamisasi di Pattani, banyak dikaitan dengan usaha kerajaan Islam Semudera Pasai pada abad ke-12 dan 13 M Yang telah begitu aktif melaksanakan dakwah Islam di kawasan ini. Raja Pattani yang pertama masuk Islam adalah Raja Paya Tu Naqpa setelah memeluk Islam mengganti namanya dengan Sultan Isma'il Zilullah Fil Alam atau lebih dikenal dengan Sultan Isma'il Syah.

Kemantapan dan kemajuan ekonomi, serta kekuatan politik Pattani yang pada masa itu kekuasaannya mencapai Klantan, Trangganu, Pahang dan Johor Baru membuat kerajaan Pattani disegani oleh negara-negara tetangga termasuk Siam. Raja Unggu (1624-1635) memutuskan hubungan dengan Siam, pemutusan hubungan diplomatik antara Pattani -Ayuthia.

Ayuthia dengan gabungan dari Ligor, Patalung, Tenassarim dan Senggara dengan bantuan tentara Belanda menyerang Pattani yang dibantu oleh Pahang,

\footnotetext{
${ }^{1}$ Haidar Putra Daulay, Dinamika Pendidikan Islam di Asia Tenggara (Jakarta: Rineka Cipta, 2009), h. 131.
} 
Johor, serta Portugis pada tanggal 11 Mei 1634, tetapi penyerangan itu dapat ditangkis dan digagalkan oleh Pattani.

Zaman kejayaan Pattani mulai menurun sejak zaman akhir pemerintahan Raja Kuning (1635-1686). Sejak saat itu mulai mengalami penurunan peranannya dalam berbagai hal. Kekacuan politik pun muncul dan hal ini tentu berpengaruh kepada perkembangan dan pertumbuhan ekonomi. Para pedagang asing tidak lagi datang ke Pattani melakukan transaksi dagang, mereka mengalihkannya ke tepat lain.

Setelah Siam dapat mengalahkan Burma pada tahun 1776, pihak Siam mengarahkan perhatiannya ke Kedah dan Pattani. Raja Siam Rama I mengutus adiknya Raja muda Putra Sarasi menyerang Pattani pada tahun 1785. Dalam keadaan yang serba kekurangan-ketika itu Pattani sedang berada dalam kemuduran-kendatipun pihak Pattani berupanya berthan namun akhirnya pada bulan November 1786. Pattani kalah.

Setelah itu konflik antara Pattani dan Siam terus berlangsung. Perang terbesar adalah peperangan yang terjadi pada tahun 1832, Melayu Pattani bergabung dengan Kedah, Klantan dan Trangganu menghadapi Siam, akan tetapi peperangan itu di akhiri dengan kemenangan Siam. Sejak era itu kekuasa Siam atas Pattani semakin kokoh dan Siam memberikan kesempatan kepada raja-raja Melayu nutuk memerintah negeri-negeri mereka sendiri dengan syarat membayar upita ke kerajaan Siam, serta bantuan tenaga manusia apabila Siam membutuhkan.

Untuk mengokohkan kekeuasaannya di Pattani maka kerajaan Siam pada tahun 1890. Menghapuskan kekuasaan raja-raja Melayu. Rencana Siam itu mendapat tentangan keras dari Tengku Adul Kadir raja Pattani yang terakhir. Beliau meminta bantuan kepada Fank Swettenham, Gubernur Negeri-negeri selat dan Negeri-negeri Melayu bersekutu serta kerajaan Inggirs agar bisa membentu rakyat Pattani. Akan tetapi usaha itu gagal, bahkan Tengku Abdul Kadir dan beberapa orang Melayu dipenjarakan dan diturunkan dari tahta kerajaan.

Pada tahun 1909. Ditandatangani sebuah perjanjian perbatasan yang disebut dengan "Perjajian Sempadan" yang dalam perjanjian itu ditetapkanlah bahwa Pattani menjadi bagian dari negeri Siam. ${ }^{2}$

Di Muangthai kaum minoritas muslim dipandang dengan sikap negatif sebagai orang "Khaek" Secara harfiah, dalam bahasa Thailand, Kata ini berarti "tamu" Masyarakat Muangthai bukanlah masyarakat yang homogen. Istilah thaiIslam atau Khaek digunakan secara resmi untuk menyebut mereka. Pada beberapa kedengarannya agak menggelikan dan berbau penghinaan. ${ }^{3}$

Kelompok Islam, yang menjadi mayoritas penduduk di negeri Thailand. sekarang tinggal di empat provinsi bagian selatan, Pattani, Yala, Narathiwat, dan Satun, juga termasuk sebagian dari provinsi Songkhla. Seluruh provinsi ini dulunya termasuk wilayah kerajaan Pattani pada abad ke-12, sebelum kerajaan

\footnotetext{
${ }^{2}$ Haidar Putra Daulay, Dinamika Pendidikan Islam di Asia Tenggara, h. 133.

${ }^{3}$ Surin Pitsuwan, terjemah, Hasan Basari, Islam di Muangthai, Nasionalisme Melayu Masyarakat Patani (Cet, I; Jakarta: LP3ES, 1989), h. 226.
} 
Sukhotai berdiri. Mereka adalah ras Melayu yang hingga kini masih mempertahankan bahasa serta budaya Melayu dalam praktik kehidupan sehariharinya. Disebutkan dalam sejarah bahwa Kerajaan Pattani merupakan salah satu negara yang makmur dan berpengaruh di Asia tenggara. ${ }^{4}$

Permasalahan yang muncul dalam masyarakat umut Islam di Thailand umumnya, dan khususnya Thailand Selatan (Pattani). Adapun masalah tersebut bersifat klasik (dulu) yaitu sudah dijelas dalam al-Qur'an, Hadis, dan kitab-kitab klasik yang di kemukakan oleh Imam Mujtahid, dan masalah yang bersifat kontemporer (baru) yaitu belum ada dalam ketentuan penetepannya. Maka masalah yang muncul di lapangan masyarakat adalah siapa yang tanggung jawab dan menyelesaikan masalah tersebut?.

Sebelum perang dunia ke-II, para pakar Ulama dalam Provinsi Pattani merasa sangan bertanggung jawab atas isu-isu yang muncul dan menimbulkan bermacam-macam perselisihan anta umat Islam di Provinsi Pattani, sedang waktu itu belum wujud suatu lembaga yang didirikan untuk menyelesaikan masalah yang timbulnya, khusus dalam Ahwal Syakhsiyah karena tidak orang yang bertanggung jawab untuk menindaklanjuti masalah tersebut. Seperti mufti, dengan keadaan yang demikian para pakar alam ulama di Provinsi Pattani bermusyawarat dan dapat mengambil keputusan, bahwa mereka mesti mengadakan satu lambaga sebagai wadah penyelesaian hal-hal mengenai agama, yang mana sekarang ini di kenal dengan nama Majlis Agama Islam.

Majlis Agama Islam di Provinsi Pattani adalah cabangan Majelis Agama Islam yang dibina pada tahun $2483 \mathrm{~B} / 1940 \mathrm{M}$ yang mana pada waktu itu para alim ulama provinsi pattani merasa bertanggung jawab atas perkara yang terjadi dalam Provinsi Pattani, karena tidak ada sesuatu lembagapun yang bertanggung jawab urusan hal-hal tenteng agama Islam sebagai Wali Amri, Mufti, dan Qadi Syar'i dalam Provinsi Pattani.

Dengan demikian, para pakar alim ulama di Provinsi Pattani dengan musyawarah dan menyatukan suara sepakat untuk mendirikan tempat penyelesaian urusan agama Islam dan sekaligus berfungsi sebagai Qadi Syar'i, yang mengurus dan mengawal umat Islam di Provinsi Pattani. ${ }^{5}$

Masyarakat umat Islam Provinsi Pattani di Thailand Selatan, menganut Mazhab Syāfi'i', sehingga dalam setiap urusan agama lebih mengutamakan pendapat ulama Syāfi'iyah atau penetapan hukumnya dalam Mazhab Syāfi'ī, namun jika mengalami kesulitan dalam menetapkan hukum satu masalah, maka dilakukan al-Ihtiyāt $\bar{i}$, yaitu memindahkan penetapan hukum berdasar mazhab yang lain dengan kesesuaian kondisinya.

Dalam perubahan sosial juga harus menekankan perkembangan fiqh Islam, karena fiqh tetap berubah mengikut pada suasana dan tempat masingmasing. Oleh karena itu, majlis agama Islam berwewenang penuh dalam

\footnotetext{
${ }^{4}$ Sudirman Tebba, Hukum Islam di Asia Tenggara (Cet, I; Bandung: Mizan, 1993), h. 118.

${ }^{5}$ Blogspot, Sejarah Pattani. 2010, http://www.blogspot.com/2010/06/sejarah-ringkasmajlis-agama-Islam.html (07 maret 2015).
} 
menganalisa, mengklasifikasi, baik fiqh bersifat klasik maupun fiqh bersifat kontemporer demi keharmonian hukum Islam. Implimentasi ijtihad dalam penetapan hukum sangat penting untuk meperoleh hasil hukum fiqh, yang mempunyai kesadaran dan ketaatan bagi umat masyarakat Provinsi Pattani Thailand Selatan.

Hukum Islam itu berdasarkan dari al-Qur'an dan Hadis Nabi saw. tetapi sekarang banyak masalah-masalah, apalagi yang berkaitan dengan masalah furü'iyah harus ditetapkan atau diputuskan hukumnya, yang tidak terdapat nashnya dalam al-Qur'an atau Hadis, kecuali harus menggunakan hasil ijtihad para Ulama mujtahid atau Ulama ahli mazhab.

Tulisan ini akan mengurai tentang bagaimana metode ijtihad Majlis Agama Islam Provinsi Pattani Thailand Selatan dalam menetapkan hukum distribusi daging qurban kepada non-Muslim.

\section{KAJIAN TEORETIK} tentang

Kajian metode hukum Islam biasanya berkenaan dengan teori klasik sumber hukum Islam, baik di kalangan ahli hukum Islam maupun para pakar hukum

Barat. Oleh karena itu, fungsi dan sifat suatu metode tidak dapat dipisahkan, bahkan dipengaruhi oleh sifat-sifat sumber hukum sendiri. Fakta historis menunjukkan bahwa pemahaman hukum Islam yang jelas telah ditempuh para sahabat Nabi saw. telah mampu memberi peran penting dalam menampakkan karakteristik hukum Islam yang dinamis dan elastis seiring dengan tuntutan zaman yang dihadapi. ${ }^{6}$

Imam Mazhab sepakat bahwa al-Qur'an dan Sunnah merupakan sumber dan dalil pokok hukum Islam begitu juga Ijma' dan qiyas sebagai dasar landasan dalam menetapkan hukum, dalam pengertiannya pun sama. Namun ada hal yang membedakan untuk menafsirkan ayat atau memahami kandungan ayat yang terdapat dalam al-Qur'an, karena al-Qur'an bersifat global. Permasalahan yang ada di sekitar kita sangat mungkin untuk dikritisi, apalagi hal-hal yang berhubungan dengan hukum syara' atau ibadah. Untuk itu, dalam mencari suatu kunci dalam pemecahan masalah, ulama biasanya menggunakan alat yang bisa memecahkan masalah tersebut antara lain dengan menggunakan al-Qur'an, sunnah, ijma' dan qiyas. Di samping itu, mereka juga harus melakukan ijtihad untuk memecahkan sebuah problematika tersebut. Maka dari itu, para ulama membuat terobosan-terobosan atau langkah-langkah untuk melakukan ijtihad sebagai solusi penyelesaian masalah-masalah yang dihadapi umat Islam. ${ }^{7}$

\footnotetext{
${ }^{6}$ Hasan Waedoloh, Tesis, Analisis Pendapat Para Ulama Tentang Hukum Distribusi Daging Qurban Kepada Non-Muslim, h. 149.

${ }^{7}$ Abd Waf Has, Jornal, Ijtihad Sebagai Alat Pemecahan Masalah Umat Islam (t.th.: Sekolah Tinggi Keislaman Al-Hidayah (STIKA) Arjasa, 2013).
} 
Ada kaitan erat antara metode hukum Islam dan karakteristik hukum Islam itu sendiri. Apabila sumber hukum Islam terdiri dari sumber wahyu dan ijtihad, metode yang dipergunakannya pun sekitar sumber tersebut. Muhammad Salam Mażkūr menyebutkan bahwa bentuk-bentuk metode hukum Islam bergantung pada landasan yang dipergunakannya dalam berijtihad atau beristinbat. Menurutnya, berdasarkan penelusuran terhadap ijtihad para sahabat Nabi saw. Oleh ksrena itu, ditinjau dari segi metodenya, sebagaimana yang dirumuskan al-Duwailibi, ijtihad dapat dibagi kepada tiga macam, yaitu ijtihad bayāni, ijtihad qiyāsi, dan ijtihad istiṣlāhi. ${ }^{8}$

\section{Ijtihad bayāni}

Ijtihad bayāni adalah menjelaskan (bayāni) hukum-hukum syar'iyah dari nash-nash syar'i (yang memberi syariat, yang menentukan syariat) atau ijtihad untuk menemukan hukum yang terkandung dalam nash, namun sifatnya zhanni, baik dari segi ketetaannya maupun dari segi penunjuknya. Lapangan ijtihad bayāni hanya dalam batas pemahaman terhadap nash dan menguatkan salah satu di antara beberapa pemahaman yang berbeda. Dalam hal ini, hukumnya tersurat dalam nash, namun tidak memberikan penjelasan yang pasti. Ijtihad di sini sifatnya hanya memberikan penjelasan hukum yang pasti dari dalil nash itu. ${ }^{9}$

Pada pendistribusian daging qurban kepada non-Muslim, ada ulama membolehkan seorang muslim memberikan daging qurban kepada non-Muslim sebagai sedeqah, atau diserahkan. Dibolehkan bagi seseorang untuk memberikan daging qurban kepada non-Muslim, dengan syarat non-Muslim tersebut bukanlah orang yang memerangi kaum muslimin (Kafir Harbi). Jika dia adalah orang yang turut memerangi kaum muslimin, maka mereka tidak boleh diberikan sedikitpun dari diging qurban, dan boleh berbuat baik kepadanya. Berdasarkan zahir nash alQur'an, Allah swt. Berfirman pada QS al- Mumtahanah/60: 8

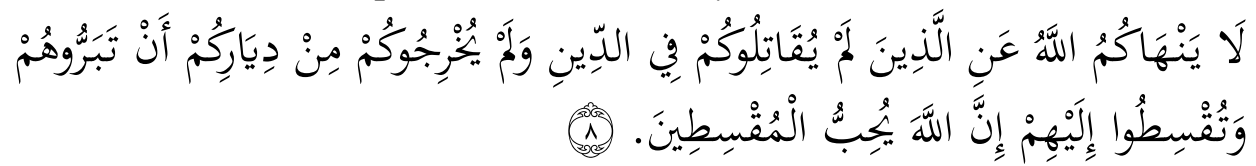

Terjemahnya:

Allah tidak melarang kamu berbuat baik dan berlaku adil terhadap orangorang yang tidak memerangimu dalam urusan agama dan tidak mengusir kamu dari kampung halamanmu. Sesungguhnya Allah mencintai orang-orang yang berlaku adil. ${ }^{10}$

Demikian Ibnu Kas̄ir menerangkan dalam kitab tafsirnya: Maksudnya adalah Allah swt. tidak melarang umat Islam untuk berbuat baik kepada orang-

\footnotetext{
${ }^{8}$ Abd. Rahman Dahlan, Ushul Fiqh, Jakarta: Amzah, 2010, h. 148.

${ }^{9}$ Totok Jumantoro, dan Samsul Munir Amin, Kamus Ilmu Usul Fikih (Jakarta: Sawo Raya, 2009), h. 114

${ }^{10}$ Kementerian Agama Republik Indonesia, Al-Qur'anul Karim: Terjemah dan Tajwid Berwarna, h. 550.
} 
orang non- Muslim yang tidak berniat membunuh dalam agama dan tidak bersekongkol untuk mengusir umat Islam. ${ }^{11}$

M. Quraish shihab menerangkan dalam buku Tafsir al-Misbah. ${ }^{12}$ Ayat di atas secara tegas menyebut nama yang maha kuasa dengan menyatakan: Allah yang memerintahkan kamu bersikap tegas terhadap orang kafir-walaupun keluarga kamu tidak melarang kamu menjalin hubungan dan berbuat baik terhadap orang-orang yang tidak memerangi kamu kerena agama dan tidak pula mengusir kamu dari negeri kamu. Allah tidak melarang kamu berbuat baiak dalam bentuk apapun bagi mereka dan tidak juga melarang kamu berlaku adil kepada mereka. Kalau demikian, jika dalam interaksi sosial mereka berada di pihak yang benar, sedang salah satu seorang dari kamu berada di pihak yang salah, maka kamu harus membela dan memenangkan mereka. Sesungguhnya Allah menyukai orang-orang yang berlaku adil.

Berdasarkan ayat di atas, menegaskan bahwa Allah swt. tidak melarang berbuat baik kepada non-Muslim yang tidak memusuhi agama Allah, seperti memberi makanan, pakaian, serta berbuat adil kepada mereka. Ayat ini bersifat umum, mencakup seluruh waktu dan tempat terhadap semua nonMuslim

asalkan sesuai dengan syarat, mereka tidak memerangi atas nama agama, mereka tidak mengusir dari kampung halaman. Betapapun agama mereka berlainan, namun mereka tetaplah makhluk ciptaan Tuhan yang berhak atas perlakuan baik selama hidup di dunia. Justru, ketika umat Islam bersikap sinis kepada mereka akan menciderai substansi Islam itu sendiri.

Dan berdasarkan soal pembahagian daging qurban dengan memberikan kepada tetangga Yahudi yang diriwayat dari Mujāhid:

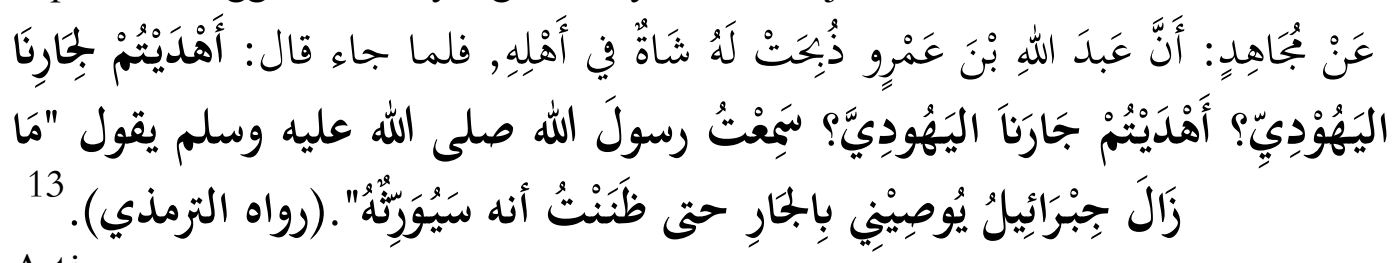

Artinya:

Dari Mujāhid bahwa 'Abdullah bin 'Amr berqurban seekor kambing untuk keluarganya, maka tatkala Abdullah datang, ia pun bertanya: Apakah engkau tela memberikan ke tetangga Yahudi kita? Dua kali, Aku mendengar Rasulullah saw. bersabda: Jibril senantiasa menasehatiku tentang tetangga, hingga aku mengira bahwa tetangga itu akan mendapat bagian harta waris. (HR Tirmiżi)

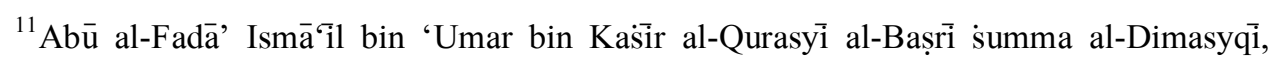
Tafsir al-Qur'ān al- 'Azìm, Juz VIII (Cet. II; t.t.: Dar Ṭayyibah, 1999), h. 90.

${ }^{12}$ M. Quraish Shihab, Tafsir al-Mishbah, Pesan, Kesan dan Keserasian Al-Qur'an (Jakarta: Juanda Ciputar, 2004), h. 168.

${ }^{13} \mathrm{Abu \overline { }}$ 'Isa,Muhammad bin 'Isā bin Saurah al-Timiżi, Sunan al-Tirmiżi (Beirut: Dar alKukub al-'Imiyah, 2008), h. 475. 
Anjuran berbuat baik kepada tetangga berlaku secara umum kepada setiap orang yang disebut tetangga, baik tetangga itu Muslim atau non-Muslim, ia tetap memiliki hak tetangga. Adapun lafal "al-Jāri” (tetangga) mencakup muslim, nonMuslim, ahli ibadah, orang fasiq, orang jujur, orang jahat, orang pendatang, orang asli pribumi, orang yang memberi manfaat, orang yang suka mengganggu, karib kerabat, ajnabi, baik yang dekat rumahnya atau agak jauh. ${ }^{14}$

\section{Ijtihad Qiyāsi}

Ijtihad Qiyāsi adalah meletakkan hukum-hukumsyar'iyah untuk kejadiankejadian (peristiwa) yang tidak terdapat di dalam al-Qur'an dan al-Sunnah, dengan jalan menggunakan qiyās atau apa yang terdapat di dalam nash-nash hukum syar'i, atau ijtihad qiyāsi merupakan ijtuhad untuk menggali dan menetapkan hukum terhadap suatu kejadian yang tidak ditemukan dalilnya secara tersurat dalam nash baik secara qath'i maupun secara zhanni, jugah tidak ada ijma' yang telah menetapkan hukumnya.

Ijtuhad dalam hai ini nutuk menetapkan hukum suatu kejadian (peristiwa) dengan merujuk pada kejadian yang telah ada hukumnya, karana antara dua peristiwa itu ada kesamaan dalam 'ilah hukumnya. Dalam hal ini, mujtahid menetapkan hukum suatu kejadian berdasarkan pada kejadian yang telah ada nashnya. Ijtihad seperti ini adalah melalui metode qiyāsi. ${ }^{15}$

Perihal pendistribusian daging qurban kepada non-Muslim, ada ulama membolehkan seorang muslim memberikan daging qurban kepada non-Muslim. Sebagai gambarannya dapat kita cermati dalam kisah Asma' binti Abu Bakar r.a. menceritakan bahwa:

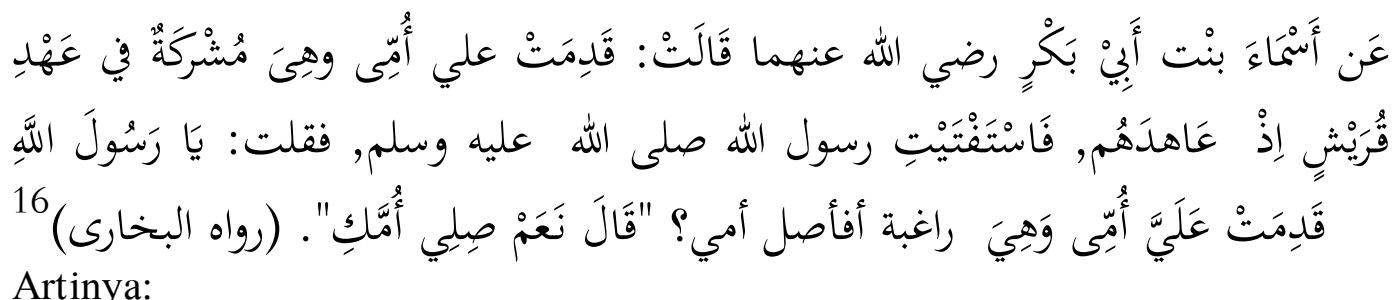

Dari Asmah binti Abu Bakar ia berkata: Ibuku datang kepadaku ketika itu masih musyrikah, maka aku pergi menemui Rasulullah saw. bertanya: apakah aku perlu menyambung silaturahmi kepadanya? Beliau menjawab, ya, sambunglah hubungan dengan ibumu. (HR Bukhari)

Pada riwayat yang lainnya dari Abdullah bin al-Zubair, ia mengatakan: Qatilah datang menemui anaknya yang bernama Asma binti Abu Bakar. Abu

${ }^{14}$ Al-Imam Muhammad Abdurrahman ibnu Abdurahim al-Mubarokfuriy, Tuhfatu Ahważi bi Syarh Jami’u Tirmiżi, juz iv (al-Qahirah: Dar al-Qudus, 2009), h. 558.

${ }^{15}$ Totok Jumantoro, dan Samsul Munir Amin, Kamus Ilmu Usul Fikih (Jakarta: Sawo Raya, 2009), h. 118

${ }^{16} \mathrm{Abi}$ 'Abdullah Muḥammad bin Ismācîl bin ibrahim, al-Bukhārīi, Ṣaḥịh al-Bukhāri, Juz III, h. 164. 
Bakar pernah menikah dan menceraikannya pada zaman Jahiliyah. Qatilah lalu dating dengan membawa hadiah-hadiah. Asma menolak pemberian hadiahhadiah tersebut atau Asma langsung masuk ke dalam rumahnya hingga mengutus Aisyah untuk menanyakan hal tersebut kepada Rasulullah saw. Aisyah lalu mengkhabarkan kepada Asma bahwa Rasulullah memerintahkan kepadanya untuk menerima hadiah-hadiah tersebut dan memasukkan ibunya tersebut ke dalam rumahnya. ${ }^{17}$

Berdasarkan hadis di atas, menegaskan bahwa Rasulullah saw. Tidak melarang berbuat baik kepada umat agama lain (non-Muslim) dari ahli zimmi, yang tidak memusuhi agama Allah, seperti memberi makanan, pakaian, sedeqah dan hadiah serta berbuat baik kepada mereka. Dalam menetapkan hukum tersebut berdasarkan kepada metode qiyas yaitu qurban merupakan makanan yang boleh dimakan sehingga boleh diberikan kepada mereka (non-Muslim) sebagaimana makanan-makanan lainnya, dan qurban merupakan sedeqah sunnah yang dianjurkan, sebagaimana sedeqah sunnah lainnya. Oleh karena, status hewan qurban sama dengan sedeqah atau hadiah.

\section{Ijtihad Istiṣlạhi}

Ijtihad istiṣlăhi adalah meletakkan (waḍ'an) hukum-hukum syar'iyah untuk peristiwa-peristiwa yang terjadi, yang untuk itu tiak terdapat di dalam alqur'an dan hadis dengan mempergunakan pandangan yang disandarkan atas istiṣlạhi atau Ijtihad istiṣlāhi adalah karya ijtihad untuk menggali, menemukan, dan merumuskan hukum syar'i dengan cara menerapkan kaidah kulliuntuk kejadian yang ketentuan hukumnya tidak terdapat nash, baik qat' $\bar{i}$ maupun zanni, dan tidak memungkinkan mencari kaitannya dengan nash yang ada, juga belum diputuskan dalam ijma'.

Dasar pegangan dalam ijtihad ini hanyalah jiwa hukum syara' yang bertujuan untuk mewujudkan kemaslahatan umat, baik dalam bentuk mendatangkan manfaat maupun menghindarkan mudharat. ${ }^{18}$

Adapun pendistribusi daging qurban kepada non-Muslim, sebagian ulama mengatakan bahwa tidak membolehkan memberi makan atau pendistribusin daging qurban kepada non-Muslim semata-mata. Dengan beralasan kemaslahatan bagi umat muslimin dan melihat secara agama yaitu:

a. Qurban adalah merupakan suatu ibadah yang diperintahkan oleh Allah swt. kepada hambanya, tujuan ibadah qurban dalam bentuk sikap kasih sayang terhadap tetamu atau tetangga sesama muslim, dengan cara memberikan makanan atau sedekahnya. Bagai mana Imam al-Ramli menyatakan tidak boleh memberikan makan dari daging qurban kepada non-Muslim sematamata, dengan beralasan bahwa tujuan ibadah qurban adalah bentuk sikap

${ }^{17}$ Hasan Waedoloh, Tesis, Analisis Pendapat Para Ulama Tentang Hukum Distribusi Daging Qurban Kepada Non-Muslim (Makassar: UIN Alauddin, 2015), h. 153.

${ }^{18}$ Totok Jumantoro, dan Samsul Munir Amin, Kamus Ilmu Usul Fikih (Jakarta: Sawo Raya, 2009), h. 116 
kasih sayang terhadap sesama muslim dengan cara memberikan makanan, selain itu qurban merupakan hidangan dari Allah swt. bagi kaum muslimin pada hari raya idul adha, karena itu hidangan ini tidak boleh diberikan kepada selain mereka. ${ }^{19}$

b. Lihat secara agama, qurban adalah urusan agama yang ada hubungan antara Tuhan dengan hamba ( Ta'abbudi) untuk hamba itu taat kepada Allah swt. Namun non-Muslim tidak ada hubungan apapun dengannya sama sekali, kerana non-Muslim adalah orang yang tidak percaya kepada Allah swt. dan rasulnya, sebagai utusan Allah. Allah swt. berfirman dalam QS alkāfirūn/109: 6

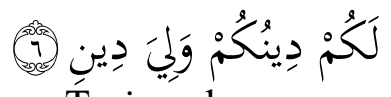

Terjemahnya:

Untukmu agamamu, dan untukkulah agamaku. ${ }^{20}$

Dan firman Allah swt. QS Yụnus/l : :

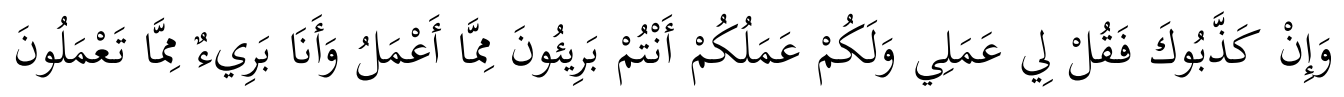

(21)

Terjemahnya:

Jika mereka mendustakaku, maka katakanlah, bagiku pekerjaanku dan bagimu pekerjaanmu. Kamu berlepas diri terhadap apa yang aku kerjakan dan aku berlepas diri terhadap apa yang kamu kerjakan. ${ }^{2}$

Dua ayat di atas menjelaskan bahwa non-Muslim tidak ada hubungan apapun dengan agama sama sesekali. maka tidak boleh memberikan daging qurban kepadanya. Dan Allah swt. berfirman bahwa mempersekutukan Allah swt. adalah benar-benar kezaliman, QS Luqmān/31:13

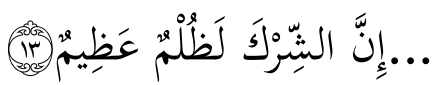

Terjemahnya:

Sesungguhnya mempersekutukan (Allah) adalah benar-benar kezaliman yang besar. $^{22}$

\footnotetext{
${ }^{19}$ Syamsu al-Din Muḥammad bin Abī al-‘Abbās Ahmad bin Hamzah bin Syihab al-Din al-Ramli, Nihāyah al-Mụtaj ilā Syarh al-Minhāj fì al-Fiqh 'alā Mażhab al-Imām al-Syāfi ī̄, Juz VIII (Cet. II; Beirut: Dar al-Kutub al-'Imiyah, 2003), h. 141.

${ }^{20}$ Kementerian Agama, Al-Qur'an Tajwid dan Terjemahnya Dilengkapi dengan Asbabun Nuzul dan Hadist Sahih, h. 603

${ }^{21}$ Kementerian Agama, Al-Qur'an Tajwid dan Terjemahnya Dilengkapi dengan Asbabun Nuzul dan Hadist Sahih, h. 213

${ }^{22}$ Kementerian Agama, Al-Qur'an Tajwid dan Terjemahnya Dilengkapi dengan Asbabun Nuzul dan Hadist Sahih, h. 412
} 


\section{METODOLOGI PENELITIAN}

Jenis penelitian dalam penelitian ini adalah penelitian kualitatif. Lokasi yang akan menjadi tempat penelitian ini di Majlis Agama Islam provinsi Pattani Thailand Selatan. Pendekatan yang digunakan dalam penelitian ini adalah pendekatan teologis normatif dan sosiologis. Sumber data primer diperoleh dari lembaga Majlis Agama Islam Provinsi Pattani Thailand Selatan, melalui wawancara dan catatannya dalam berijtihad tentang hukum distribusi daging qurban kepada non-muslim. Data dikumpulkan dengan metode wawancara, observasi, dan dokumentasi dengan instrumen penelitian adalah pedoman wawancara dan pedoman observasi. Teknik pengolahan dan analisis terhadap data dilakukan dengan reduksi data, display data dan verifikasi data. Pengujian keabsahan data, peneliti menekankan pada uji kredibilitas data atau kepercayaan terhadap hasil penelitian melalui beberapa tahap antara lain; memperpanjang pengamatan, meningkatkan ketekunan dalam penelitian, melaksanakan triangulasi sumber data maupun teknik pengumpulan data, melakukan diskusi dengan sejawat/orang yang berkompeten menyangkut persoalan yang sedang diteliti, serta mengadakan member chek untuk memastikan kesesuaian data yang telah diberikan oleh pengurus.

\section{HASIL PENELITIAN DAN PEMBAHASAN}

Pada dasarnya ajaran Islam dapat dibedakan menjadi dua kelompak ajaran. Pertama, ajaran Islam yang bersifat absolut, universal dan permanen, tidak berubah dan tidak dapat diubah. Termasuk didalamnya adalah yang tercentum dalam al-Qur'an dan hadis mutawatir yang penunjukannya telah jelas. Kedua ajaran Islam yang bersifat relatif, tidak universal dan tidak permanen, dapat berubah dan diubah. Termasuk kelompok ajaran ini ialah ajaran islam yang dihasilkan dari proses ijtihad.

Di samping adanya dikotomi antra dalil qath'i dengan dalil zanni, baik eksistensinya maupun penunjukannya, yang menjadi bahan pembicaraan di kalangan ahli hukum Islam dan pakar pembaharuan dalam Islam, ajaran Islam yang termasuk kelompak nisbi dan kontemporer ternyata lebih banyak jumlahnya jika dibandingkan dengan ajaran Islam yang bersifat absoiut dapat dikemukakan bahwa permasalahan yang muncul pada masa Nabi saw. lebih sedikit dibandingkan dengan zaman-zaman sesudahnya, sementara al-Qur'an tetap satu.

Ijtihad dalam pengertian luas berarti menggunakan daya nalar untuk menghasilkan hukum syar'i. Ijtihad merupakan proses berpikir dalam memahami al-Qur'an dan susnah. Ijtihad merupakan suatu kesimpulan logis dalam masalah hukum yang dilakukan untuk mengaktualisasikan ajaran hukum. Apabila seorang tidak mempergunakan akalnya, maka orang tersebut tidak akan mampu memahami ajaran-ajaran agama. Olehnya itu, akal merupakan karunia Allah 
terbesar, terutama untuk memperoleh kesimpulan logis atas masalah-masalah yang dihadapi. ${ }^{23}$

Keberadaan metode dalam penetapan fatwa adalah sangat penting, sehingga dalam setiap proses penetapan fatwa harus mengikuti metode tersebut. Sebuah fatwa yang ditetapkan tanpa mempergunakan metodologi, keputusan hukum yang dihasilkannya kurang mempunyai argumentasi yang kokoh. Oleh karenanya, implementasi metode (manhaj) dalam setiap proses penetapan fatwa merupakan suatu keniscayaan. ${ }^{24}$

Imam Mazhab sepakat bahwa al-Qur'an dan hadis merupakan sumber utama dan dalil pokok hukum Islam begitu juga Ijma' dan qiyas sebagai dasar landasan dalam menetapkan hukum Syar'i, dalam pengertiannya pun sama. Namun ada hal yang membedakan untuk menafsirkan ayat atau memahami kandungan ayat yang terdapat dalam al-Qur'an, karena al-Qur' an bersifat global. Permasalahan yang ada sangat mungkin untuk dikritisi, apalagi hal-hal yang berhubungan dengan hukum Syar'i atau ibadah. Untuk itu, dalam mencari suatu kunci dalam pemecahankan masalah, ulama biasanya menggunakan alat yang bisa memecahkan masalah tersebut apalagi masalah furu'iyah antara lain dengan menggunakan al-Qur'an, hadis, ijma' dan qiyas. Di samping itu, mereka juga harus melakukan ijtihad untuk memecahkan sebuah problematika tersebut.

Dasar penetapan hukum Syar'i di Majelis Agama Islam Provinsi Pattani bermazhab Syāfi'i, bukan hanya berdasarkan kepada sumber yang Muttāfã $q$ saja, namun boleh berdasarkan pada dalil yang Mukhtālāf seperti: maslahah almursalah dan maqāsid al-syarí'ah. Dengan dasar penetapan hukum tersebut selaras dengan metode ijtihad yang dikemukakan oleh Wahbah al-Zuhaili, yaitu metode bayāni, metode qiyāsi, dan metode istiṣlăhi. Karena memenuhi atau melengkapi dalil-dalil yang digunakan dalam mazhab Syāfi'i, sebagai implementasi kesesuaian metode ijtihad di masyarakat Patani. Adapun metode ijtihad Majlis Agama Islam Provinsi Pattani dalam menetapkan hukum distribusian daging qurban kepada non-Muslim, adalah metode Ijtihad bayāni dan metode Ijtihad istișlāhi:

1. ijtihad bayāni

Ijtihad bayāni adalah menjelaskan (bayāni) hukum-hukum syar'iyah dari nash-nash syar'i (yang memberi syariat, yang menentukan syariat) atau ijtihad untuk menemukan hukum yang terkandung dalam nash, namun sifatnya zanni, baik dari segi ketetapannya maupun dari segi penunjuknya. Lapangan ijtihad bayāni hanya dalam batas pemahaman terhadap nash dan menguatkan salah satu di antara beberapa pemahaman yang berbeda. Dalam hal ini, hukumnya tersurat dalam nash, namun tidak memberikan penjelasan yang pasti. Ijtihad di sini sifatnya hanya memberikan penjelasan hukum yang pasti dari dalil nash itu. ${ }^{25}$

Dalam al-Qur'an Allah swt. berfirman QS al- Mumtahanah/60: 8-9

${ }^{23}$ Muhammad Shuhufi, Fatwa dan Dinamika Hukum Islam di Indonesia (Makassar: Jalan Sultan Alauddin, 2011), h. 75.

\footnotetext{
${ }^{24}$ Muhammad Shuhufi, Fatwa dan dinamika hukum Islam di indonesia, h. 147

${ }^{25}$ Totok Jumantoro, dan Samsul Munir Amin, Kamus Ilmu Usul Fikih, h. 114.
} 


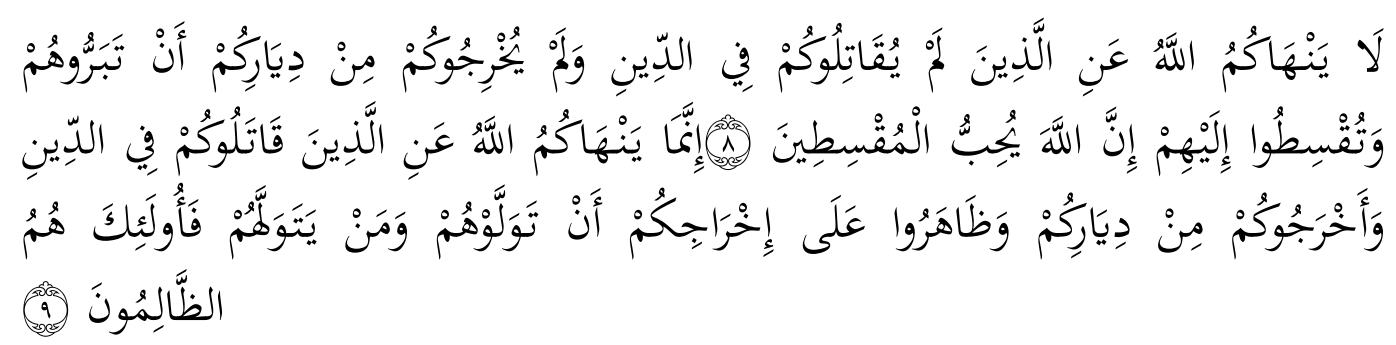

Terjemahnya:

Allah tidak melarang kamu berbuat baik dan berlaku adil terhadap orangorang yang tidak memerangimu dalam urusan agama dan tidak mengusir kamu dari kampung halamanmu. Sesungguhnya Allah mencintai orang-orang yang berlaku adil". Sesungguhnya Allah hanya melarangmu menjadikan kawanmu orang-orang yang memerangimu karena agama dan mengusirmu dari negerimu dan membantu (orang lain) untuk mengusirmu dan barang siapa menjadikan mereka sebagai kawan, maka mereka itulah orang-orang yang zhalim. ${ }^{26}$

Ibn Kasīr menerangkan dalam kitab tafsïrnya, maksud dari ayat: لَ يَنْهَاكُكُ

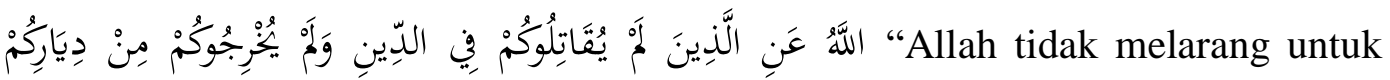
berbuat baik dan berlaku adil terhadap orang yang tidak memerangimu kerana agama dan tidak pula mengusirmu dari negerimu." Maksuknya, mereka yang telah membantu mengusir kalian. Artinya, Allah tidak melarang kalian berbuat baik kepada orang-orang kafir yang tidak memerang kalian karena agama, seperti

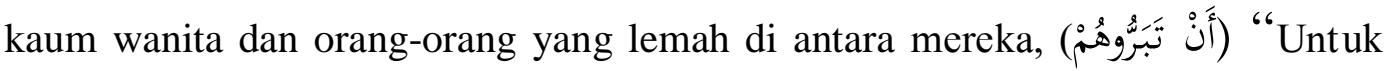
berbuat baik kepada mereka," yakni berlaku baik terhadap mereka. ( وَتُقْسِطُوا إلَيْهِهْ Serta berlagu adil terhadap mereka. Sesungguhnya Allah menyukai orang-orang yang berlaku adil.

Adapun asbabul nuzul ayat tersebut; Iman Ahmad meriwayatkan dari Asma' binti Abi Bakar, ia bercerita:

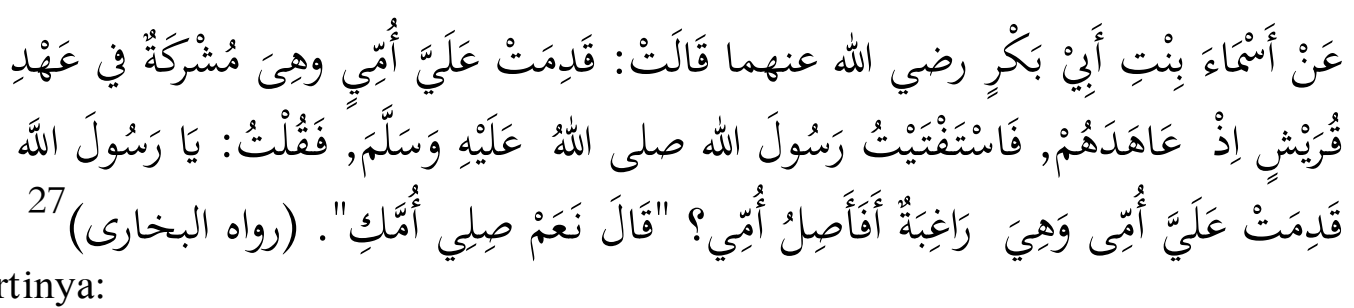
Artinya:

${ }^{26}$ Kementerian Agama Republik Indonesia, Al-Qur'anul Karim: Terjemah dan Tajwid Berwarna, h. 550.

${ }^{27}$ Abi 'Abdullah Muhammad bin Ismā‘ ‘il bin ibrahim, al-Bukhārī, Ṣaḥịh al-Bukhāri, Juz III, h. 164. 
Ibuku pernah datang kepadaku sedang ia dalam keadaan musyrik, pada waktu kaum Quraisy melakukan perdamaian (Hudaibiyyah). Lalu kukatakan: "Ya Rasulullah saw. sesungguhnya ibuku datang kepadaku dan berharap (dai dapat bertemu denganku), apakah aku boleh menyambung hubungan dengannya? Beliau mejawab: Ya, sambunglah hubungan dengan ibumu. (HR Bukhari).

Iman Ahmad juga meriwayatkan dari riwayat yang lain, 'Arim memberitahu kami, 'Abdullah Ibn al-Mubarak memberitahu kami, Mush'ab Ibn sabit memberitahu kami, 'Amir Ibn 'Abdullah Ibn al-Zubir memberitahu kami, dari ayahnya, ia bercerita "Qutailah pernah datang menemui puterinya (Asma' binti Abu Bakar) dengan membawa daging dhabb, dan minyak samin sebagai hadiah, sedang ia seorang wanita musyrikah, maka Asma' pun menolak pemberiannya itu dan memasukkan ibunya kerumahnya, kemudian 'Aisyah bertanya kepada Nabi saw. Lalu Allah swt. menurunkan ayat:

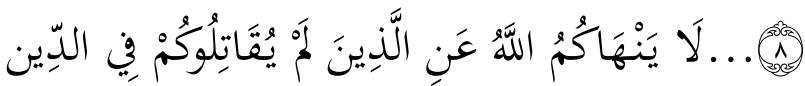

Firmannya lebih lanjut:

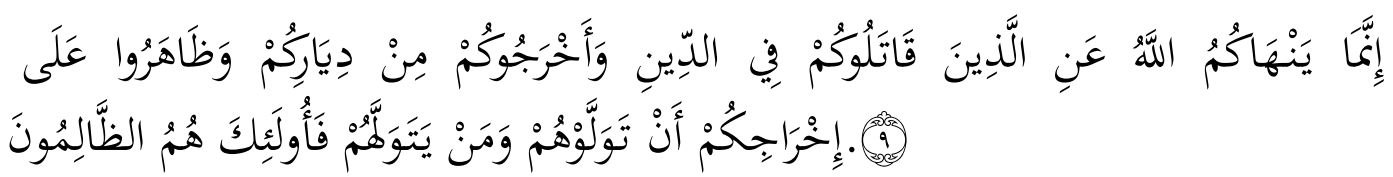

Terjemahnya:

Sesungguhnya Allah swt. hanya melarang kamu menjadikan mereka sebagai kawanmu orang-orang yang memerangi kamu dalam urusan agama dan mengusir kamu dari kampung halamanmu (negerimu) dan membantu (orang lain) untuk mengusirmu. Barang siapa menjadikan mereka sebagai kawan, maka mereka itulah orang-orang yang zalim. ${ }^{28}$

Maksudnya, Allah melarang berteman dengan orang-orang yang telah melancarkan permusuhan terhadapnya, kemudian mereka memerangi dan mengusir kalian dan bantu membantu untuk mengusir. Allah yang Mahaperkasa lagi Mahamulia, melarang kalian menjadikan mereka sebagai teman, dan bahkan memerintahkan kalian memusuhi mereka. Kemudian Allah swt. mempertegas ancaman bagi orang-orang yang menjadikan mereka sebagai teman, Allah swt.

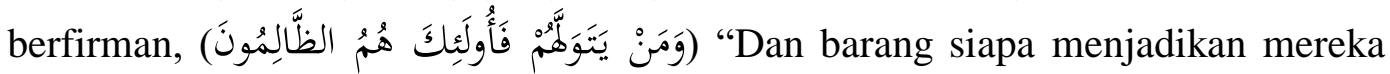
sebagai teman, maka mereka itulah orang-orang yang zalim." 29

Allah swt. melarang dengan keras dari mencintai orang-orang yang memusuhi dan memerangi orang-orang yang beriman dalam agama dan mengeluarkan mereka dari tanah air mereka sendiri atau orang-orang kafir itu membantu dalam pengusiran atas mereka darinya.

\footnotetext{
${ }^{28}$ Kementerian Agama Republik Indonesia, Al-Qur'anul Karim: Terjemah dan Tajwid Berwarna, h. 550.

${ }^{29}$ M. Abdul Ghoffar, Abdurrahman Mu'thi, Abu Ihsan Al-Atsari, Terj, Tafsir Ibnu Kasir, jilid viii, h. 142.
} 
Allah memvonis bahwa kaum muslimin yang menjadikan orang-orang kafir musyrik sebagai teman dan penolong. Padahal, mereka memusuhi orangorang yang beriman, sebagai orang-orang yang zalim. Dan di antara makna zalim itu adalah syirik seperti firman Allah swt. QS Luqman/31: 13

Terjemahnya:

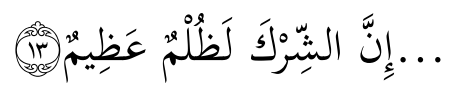

Sesungguhnya mempersekutukan Allah swt. adalah benar-benar kezaliman yang besar. ${ }^{30}$

Majlis Agama Islam Provinsi Pattani adalah satu lembaga tujuannya untuk menyelesaikan masalah hukum agama Islam dan untuk melahirkan kesatuan dalam masyarakat.

"Mengenai hukum distribusian daging qurban kepada non-Muslim terdapat perbedaan di antra para ulama fuqaha. Ada yang dibolehkan dengan syarat qurban sunnat dan ahli zimmah. Dan yang mengharamkan yakni tidak boleh sama sekali diberi kepada non-Muslim. Sebenarnya Allah swt. tidak melarang berbuat baik, berlaku adil kepada orang-orang kafir yang tidak memerang kerana agama dan tidak mengusir dari negeri dan membantu orang lain untuk mengusir, seperti kaum wanita dan orangorang yang lemah. Sementara Allah melarang dengan keras dari mencintai, barbuat baik dan barlagu adil terhadap orang-orang yang memusuhi dan memarangi orang-orang yang beriman dan mengeluarkan mereka dari tanah air mereka sandiri. Barang siapa menjadikan mereka sebagai teman dan berbuat baik, maka mereka itulah orang-orang yang zalim. seperti mana Allah berfirman dalam al-Qur'an sura al-Mumtahanah/60: 8-9. Dan di antara makna zalim itu adalah syirik atau mempersekutukan Allah swt. Sementara non-Muslim di Pattani adalah non-Muslim budha yakni kafir musyrik beragama budha, tidak beriman kepada Allah swt. dan Rasul, bukan agama samawi dan bukan ahli ibadah. Sementara daging qurban adalah daging ibadah, maka yang boleh diberi hanya kepada ahli ibadah. Dan non-Muslim di Pattani adalah kafir harbi yakni ahli harbi. Kerana Pattani adalah satu daulah Islam, pada tahun $1785 \mathrm{M}$ Thailand masuk menyerang Pattani dan mengusirkan masyarakat Pattani. Pada tahun 1786 M Pattani kalah, dengan itu, sistem pemerintahan kesultanan Melayu Islam Pattani telah dihapuskan. Pada tahun 1909 M Pattani dijajahan oleh Thailand dan menjadi sebagian dari negeri Thailand hingga sekarang. Adapun Thailand tidak pernah melaku adil terhadap masyarakat Muslim di Pattan. Seperti yang diungkap oleh W.A.R. WOOD. Konsul Britania di Songkhla, penduduk Melayu Islam Pattani telah menjadi mangsa sebuah pemerintahan yang tidak diperintah dengan baik. Maka Majlis Agama Islam Provinsi Pattani difatwakan bahwa hukum distribusian daging qurban kepada non-Muskin di Pattani adalah haram. yakni tidak boleh sama sekali memberikan daging qurban kepada non-Muslim, sebagai sedekah dan hadiah atau memberi makan kepadanya. Kalau diberi makan

${ }^{30}$ Kementerian Agama Republik Indonesia, Al-Qur'anul Karim: Terjemah dan Tajwid Berwarna, h. 412. 
atau sedekah dari daging qurban kepada non-Muslim, wajib digantikan dengan daging yang laian."

Dan berdasarkan soal pembahagian daging qurban dengan memberikan kepada tetangga yahudi, dari Mujāhid:

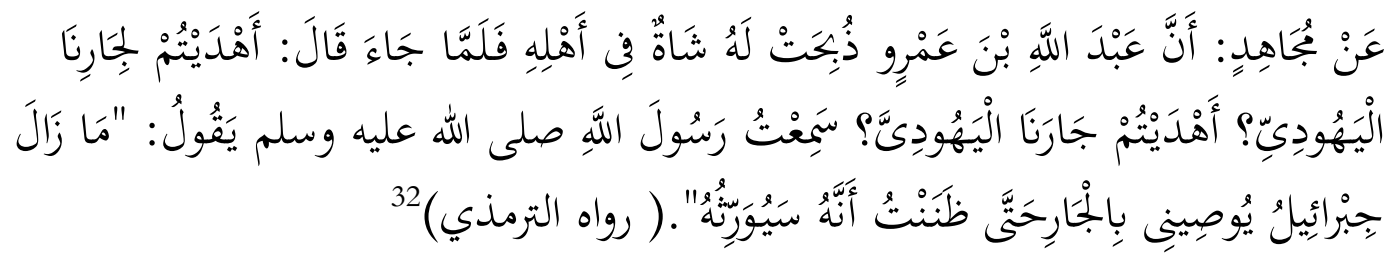

Artinya:

Dari Mujahid bahwa 'Abdullah bin 'Amr berqurban seekor kambing untuk keluarganya, maka tatkala Abdullah datang, ia pun bertanya: Apakah engkau tela memberikan ke tetangga Yahudi kita? Dua kali, Aku mendengar Rasulullah saw. bersabda: Jibril senantiasa menasehatiku tentang tetangga, hingga aku mengira bahwa tetangga itu akan mendapat bagian harta waris. (HR Tirmizi)

"Majlis Agama Islam Provinsi Pattani mengguna hadis diatas sebagai dalil kerana, bahwa hadis tersebut menggunakan lafal " اليَهُودِى " (Yahudi). Kalau daging qurban itu boleh diberikan kepada non-Muslim secara umum tentu hadis tersebut tidak menggunakan lafal itu, (Yahudi), maknanya yang boleh diberikan daging qurban sesama Muslim dan kepada non-Muslim "yahudi". Kerana yahudi adalah agama samawi dan ahli ibadah. Setiap Nabi yang diutus oleh Allah swt. mengajak untuk beribadah hanya kepada Allah swt. yang tidak sekutu baginya, dan fitrah yang menjadi saksi hal tersebut. Sedangkan orang-orang musyrik yakni kafir musyrik tidak memiliki bukti dan hujjah yang jelas di sisi Tuhan mereka, mereka yang kafir tetapi bukan pemeluk agama samawi, juga bukan ahli kitab. Sementara non-Muslim di Pattani adalah kafir musyrik agama budha, tidak beriman kepada Allah dan Rasul. Maka Majlis Agama Islam Provinsi Pattani difatwakan bahwa tidak boleh diberikan daging qurban kepadanya."33

Sebagaimana Allah swt. ditegaskan dalam al-Qur'an bahwa agama yang diturunkan oleh Allah swt. kepada para Nabi-Nabi dan Rasul pada dasarnya adalah sama. Allah berfirman QS al-Anbiyāa/21: 25

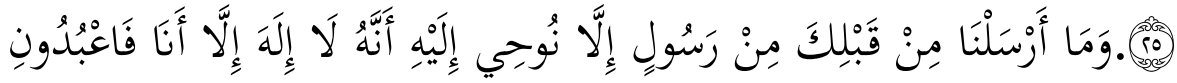

Terjemahnya:

${ }^{31}$ Wawancara langsung dengan badan Syar'i, dan badan Pelajaran dan Pendidikan, Pattani, 17 October, 2018.

${ }^{32} \mathrm{Abi}$ 'Isāa Muhammad bin 'Isā bin Saurah al-Tirmiżi , Sunan al-Tirmiżi, h. 475.

${ }^{33}$ Wawancara langsung dengan badan Syar'i, dan badan Pelajaran dan Pendidikan, Pattani, 17 October, 2018. 
Dan kami tidak mengutus sorang Rasul pun sebelum kamu, melainkan kami wahyukan kepadanya, bahwasanya tidak ada Ilah yang haq melaikan aku (Allah swt.) maka sembahlah olehmu sekalian aku. ${ }^{34}$

Dalam al-Qur' an Allah swt. berfirman. QS al-Syura/24: 13

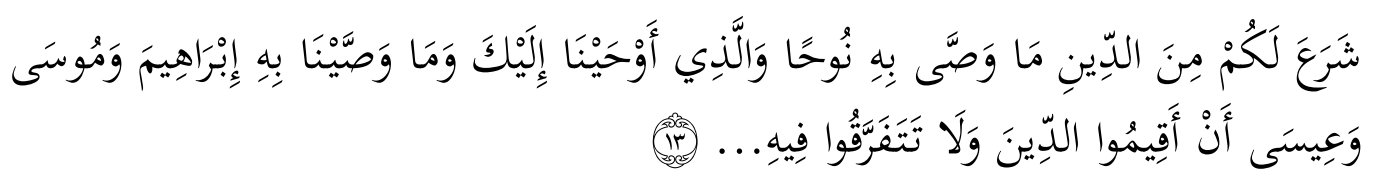

Terjemahnya:

Allah telah menerangkan kepadamu dari (urusan) agama yang telah diwajibkan kepada Nuh dan yang telah Kami wahyukan kepadanya dan apa yang telah kami wajibkan kepada Ibrahim, Musa dan Isa, yakni handaknya kamu menegakkan agama dan jangan bercerai-berai tentang urusan agama.

Kaum muslimin dituntut untuk mempercaya dan beriman kepada semua kitab yang diturunkan oleh Allah swt. dan segenap para Nabi-Nabi dan Rasulnya. Sedangkan kafir musyrik tidak percaya dan tidak beriman kepada Allah dan Rasul. Namun konsep mereka ketuhanan mereka adalah mengakui adana tuhan selain Allah swt. baik berbentuk berhala batu, atau pun menyerahkan diri mereka kepada kekuatan ghaib.

Demikian Imam Qurtubī mejelaskan dalam buku "al-Jāmi'u li Ahkami alQur'an, Ii abu Abdullah Muhammad Ibn Ahmad al-Anshari, al-Qurtubi" ulama berkata:

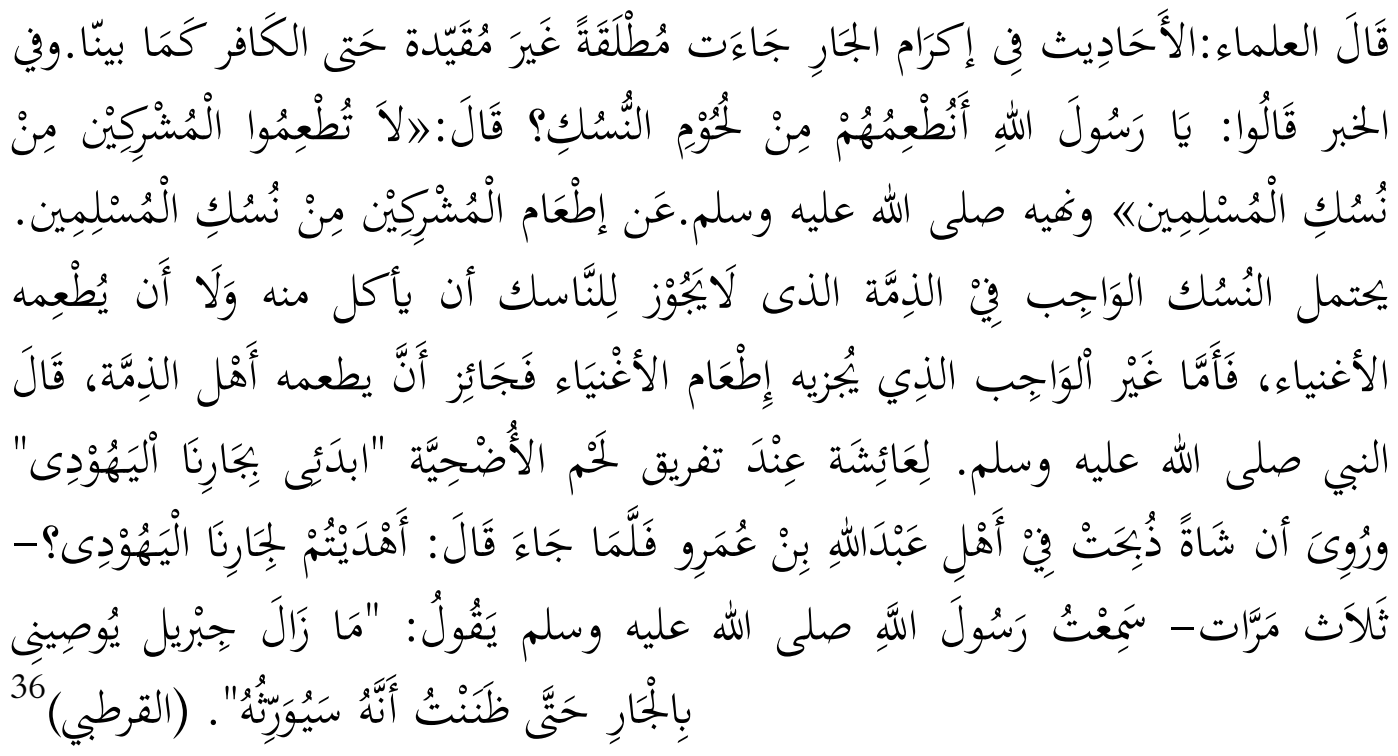

\footnotetext{
${ }^{34}$ Kementerian Agama Republik Indonesia, Al-Qur'anul Karim: Terjemah dan Tajwid Berwarna, h. 324.

${ }^{35}$ Kementerian Agama Republik Indonesia, Al-Qur'anul Karim: Terjemah dan Tajwid Berwarna, h. 484.

${ }^{36} \mathrm{Abi}$ Abdullah Muhammad bin ahmad al-anshari, al-Qurthubiy, Jami'u li ahkami alQur'an, Tafsir al-Qurtubi, juz v, (Beirut: Dar al-Fikri, 1987), h. 188.
} 
Artinya:

Para ulama berkata, "Hadis-hadis yang menerangkan tentang memuliakan tetangga bersifat muthlaq dan tidak mengikat muqayyad bahkan hal ini juga berlaku kepada orang kafir sebagaimana yang telah kami jelaskan sebelumnya." Dalam riwayat lain para sahabat bertanya, "Wahai Rasulullah, apakah kami boleh memberi makan kepada (orang kafir) daging-daging qurban? beliau menjawab: janganlah kalian memberi makan mereka dengan daging qurban kaum muslimin." Hadis ini menerangkan bahwa Rasululah saw. melarang memberi makan orang kafir dengan daging binatang qurban orang-orang muslimin. Karena terdapat kemungkinan daging qurban tersebut tidak boleh dikomsumsi oleh orang yang wajib berqurban atau orang kaya, sedangkan orang yang tidak wajib berqurban boleh memberikan daging qurbannya kepada orang kaya ataupun ahlu zimmah, sebagaimana sabda Nabi saw. kepada Aisyah, tatkala ia membagi-bagikan daging qurban, "Mulailah membagi daging qurban kepada tetangga kita yahudi". Riwayat lain menyebutkan bahwa seekor kambing disembelih oleh keluarga Abdullah bin Amru, dan tetkala Rasululah saw. datang beliau bertanya, "Apakah kalian telah membagikan daging qurban kepada tetangga kita orang yahudi? Beliau mengucapkannya hingga tiga kali. Aisyah mendengar Rasulullah saw.

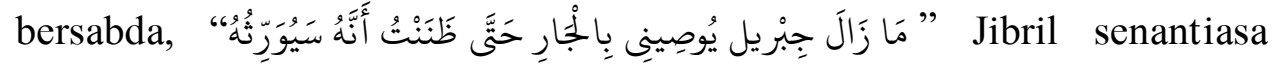
mewasiatkanku tentang (hak-hak) tetangga, sampai-sampai aku mengira mereka akan mendapatkan warisan. (al-Qurțubi)

Anjuran berbuat baik terhadap tetangga berlaku secara umum kepada setip orang yang disebut tetangga, walaupun ia non-Muslim, ia tetap memiliki hak tetangga. Namun mengenai distribusian daging qurban, maka hanya dibolehkan memberi sesama muslim, dan ahli kitab. Kerana qurban adalah ibadah untuk hamba tambah taat dan mendekatkan diri kepada Allah swt.

2. Ijtihad istiṣlähi

Ijtihad istișlāhi adalah meletakkan (waḍ'an) hukum-hukum syar'iyah untuk peristiwa-peristiwa yang terjadi, yang untuk itu tidak terdapat di dalam alqur'an dan hadis dengan mempergunakan pandangan yang disandarkan atas istiṣlăhi atau Ijtihad istiṣlāḥi adalah karya ijtihad untuk menggali, menemukan, dan merumuskan hukum syar'i dengan cara menerapkan kaidah kulli untuk kejadian yang ketentuan hukumnya tidak terdapat nash, baik qat' ${ }^{\prime} \bar{i}$ maupun zanni, dan tidak memungkinkan mencari kaitannya dengan nash yang ada, juga belum diputuskan dalam ijma'.

Dasar pegangan dalam ijtihad ini hanyalah jiwa hukum syar'i yang bertujuan untuk mewujudkan kemaslahatan umat, baik dalam bentuk mendatangkan manfaat maupun menghindarkan mudharat. ${ }^{37}$

"Qurban merupakan salah satu ibadah yang disyariatkan oleh Allah swt. sebagai sarana untuk mendekat kepadanya dan merupakan pendidikan keikhlasan dalam beramal. Seorang Muslim yang berqurban pada setiap

\footnotetext{
${ }^{37}$ Totok Jumantoro, dan Samsul Munir Amin, Kamus Ilmu Usul Fikih, h. 116.
} 
tahunnya berarti ia telah melakukan sebuah latihan beramal yang diliputi oleh rasa ikhlas. Kerana ikhlas dalam beramal merupakan salah satu kunci dalam beribadah. Adapun pembahagian daging qurban kepada nonMuslim, tidak ada nash yang jelas dalam al-Qur'an, hadis dan ijmah ulama pada masalah ini. Qurban adalah merupakan suatu ibadah yang diperintahkan oleh Allah swt. kepada hambanya, tujuan qurban dalam bentuk sikap kasih sayang atau belas kasihan terhadap umat sesama muslim yakni tetangga fakir dan miskin atau pun kaya, dengan cara memberikan makanan dan sedekah kepadanya. Dan qurban suatu urusan agama untuk mendekatkan diri kepada Tuhan atau hubungan antara Tuhan dengan hamba ( Ta'abbüdi) sepaya hamba taat dan mendekatkan diri kepada Allah swt. Sedangkan non-Muslim di Pattani adalah kafir musyrik beragama budha, yakni tidak beriman kepada Allah swt. dan Nabi-nabi maka bukan pemeluk agama samawi dan jiga bukan ahli kitab. Maka tidak boleh diberikan makan atau sedekah dari daging ibadah kepadanya. ${ }^{38}$

Dari penjelasan, bahwa Majlis Agama Islam Provinsi Pattani Tailand Selatan berpandangan bahwa tidak boleh sama sekali memberikan makan atau sedekah daging qurban kepada non-Muslim di Pattani, kerana non-Muslim di Pattani adalah kafir musyrik agama budza. Sekiranya terbagi harus menggantikan denagn daging yang lain. dan juga bagi orang yang terdapat daging qurban dari kalangan orang kaya maupun orang miskin yakni tidak boleh memberikan daging tersebut kepada non-Muslim. Melainkan dalam hal keadaan darurat, mereka datang kerumah, tetapi tidak ada makanan yang lain kecuali daging qurban, maka boleh memberi makan kepadanya dari daging qurban supaya menyelesaikan darurat itu, tetapi setelah itu harus menggantikan dengan daging lain.

Adapun metode ijtihad yang digunakan oleh Majlis Agama Islam Provinsi Pattani, yaitu metode ijtihad bayāni, dan metode ijtihad istiṣlăhi. Bahwa model ijtihad tersebut dalam kaitan dengan mashlahah sebagai tujuan syar'i, merupakan model dalam rangka memahami tujuan penetapan hukum Islam, yaitu mașlahah al-mursalah, dan maqāsidal-syarī'ah. Oleh karena itu, kesesuaian metode ijtihad dalam penetapan hukum/fatwa pada Lembaga Majelis Agama Islam di Patani didasarkan kepada metode tersebut, karena memenuhi/melengkapi dalildalil yang digunakan dalam mazhab Syāfi'i sebagai implementasi kesesuaian metode ijtihad fikih di masyarakat Pattani.

Setiap penetapan hukum/fatwa yang ditetapkan tergantung kesesuaian dalam kondisi orang tertentu dengan mengetahui dan mempelajari bagaimana kebolehan dan larangan terhadap masalah tersebut, bukan karena semata-mata ikut kemauan diri dan mengacuhkan apa yang diajarkan agama Islam. Sesungguhnya bentuk-bentuk metode ijtihad hukum Islam tidak dapat dipisahkan dengan objek kajian. Berdasarkan hasil analisis tentang metode ijtihad dalam menetapkan hukum tersebut.

${ }^{38}$ Wawancara langsung dengan badan Syar'i, dan badan Pendidikan dan Pelajaran, Pattani, 17 October, 2018. 


\section{V.PENUTUP}

Berdasarkan paparan di atas maka dapat disimpulkan bahwa metode ijtihad Majlis Agama Islam Provinsi Pattani Thailand Selatan dalam menetapkan hukum distribusian daging qurban kepada non-Muslim. Menggunakan metode ijtihad bayāni dan metode ijtihad istiṣlāhi. Metode ijtihad bayāni yang berdasarkan kepada zahir nash al-Qur'an dan hadis Nabi saw. Adapun ijtihad istiṣlăhi, melihat secara kemaslahatan dan keagamaan yaitu tujuan ibadah qurban dalam bentuk sikap kasih sayang terhadap umat sesama muslim dengan cara memberikan makanan atau sedekah kepadanya. Dan qurban merupakan suatu ibadah, untuk hamba taat dan mendekatkan diri kepada Allah swt. maka yang boleh hanya ahli ibadah. Sementara non-Muslim di Pattani adalah kafir musyrik beragama budha yakni bukan ahli ibadah.

\section{DAFTAR PUSTAKA}

Blogspot, Sejarah Pattani. 2010, http://www.blogspot.com/2010/06/sejarahringkas-majlis-agama-Islam.html (07 maret 2015).

Bukhāri, Abi 'Abdullah Muhammad bin Ismā‘il bin Ibrahim, al-', Saḥịh alBukhäri, Juz III.

Daulay, Haidar Putra, Dinamika Pendidikan Islam di Asia Tenggara Jakarta: Rineka Cipta, 2009.

Ghoffar, M. Abdul, Abdurrahman Mu'thi, Abu Ihsan Al-Atsari, Terj, Tafsir Ibnu Kasir, jilid viii.

Has, Abd Waf, Jornal, Ijtihad Sebagai Alat Pemecahan Masalah Umat Islam, t.th.: Sekolah Tinggi Keislaman Al-Hidayah (STIKA) Arjasa, 2013.

Ibn Katsir, Abū al-Fadā' Ismā'il bin 'Umar bin Kas̄ìr al-Qurasyī al-Bașrì ṡumma al-Dimasyqì, Tafsìr al-Qur'ān al-'Azìim, Juz VIII Cet. II; t.t.: Dar Ṭayibah, 1999.

Jumantoro, Totok, dan Samsul Munir Amin, Kamus Ilmu Usul Fikih Jakarta: Sawo Raya, 2009

Mubarokfuriy, Al-Imam Muhammad Abdurrahman ibnu Abdurahim al-, Tuhfatu Ahwȧi bi Syarh Jami’u Tirmiżi, juz IV al-Qahirah: Dar al-Qudus, 2009.

Pitsuwan, Surin, terjemah, Hasan Basari, Islam di Muangthai, Nasionalisme Melayu Masyarakat Patani, Cet, I; Jakarta: LP3ES, 1989. 
Qurthubiy, Abi Abdullah Muhammad bin ahmad al-anshari, al-, Jami'u li ahkami al-Qur'an, Tafsir al-Qurtubi, juz v, Beirut: Dar al-Fikri, 1987.

Shihab, M. Quraish, Tafsir al-Mishbah, Pesan, Kesan dan Keserasian Al-Qur'an Jakarta: Juanda Ciputar, 2004.

Shuhufi, Muhammad, Fatwa dan Dinamika Hukum Islam di Indonesia Makassar: Jalan Sultan Alauddin, 2011.

Syamsu al-Din Muhammad bin Abī al-'Abbās Ahmad bin Hamzah bin Syihab alDin al-Ramīi, Nihāyah al-Muhtaj ilā Syarh al-Minhāj fì al-Fiqh 'alā Mażhab al-Imām al-Syāfi î̀, Juz VIII Cet. II; Beirut: Dar al-Kutub al'Imiyah, 2003.

Tebba, Sudirman, Hukum Islam di Asia Tenggara, Cet, I; Bandung: Mizan, 1993.

Timiżi, Abū 'Isa,Muhammad bin 'Isā bin Saurah al-, Sunan al-Tirmiżi Beirut: Dar al-Kukub al-'lmiyah, 2008.

Waedoloh, Hasan, Tesis, Analisis Pendapat Para Ulama Tentang Hukum Distribusi Daging Qurban Kepada Non-Muslim.

Wawancara langsung dengan badan Syar'i, dan badan Pelajaran dan Pendidikan, Pattani, 17 October, 2018. 